\title{
Leaving Islam from a Queer Perspective
}

\author{
Erica Li Lundqvist
}

This chapter puts queer theory in dialogue with the study of religion, specifically in relation to Islamic studies and those who have left their religion or are in the process of doing so. It also explores the intersection of sexuality and religion and uses queer theory to investigate the taken-for-granted categories of "normal" and "natural," asking what they mean in religious terms when religion is studied as a socially constructed and cultural phenomenon.

Queer theory does not consist of just one theory, or even a number of clearly formulated theories, but of several different perspectives and ways of interpreting society, culture, and identity (Kulick 1996; Kulick 2005). Queer theory draws on poststructuralism, deconstruction, and psychoanalysis, and scholars such as Michel Foucault (1978), Eve Sedgwick (1990), and Judith Butler (1990, 2003) are major influences in the field. One feature common to all queer perspectives is critique of what is perceived as normative, destabilising the status of norms as "given" or taken for granted. If we apply a queer perspective to people who are leaving religion, rejecting religiosity or religious faith altogether, then the irreligious position can, on one hand, be understood as opposing religious norms and, on the other, also be destabilised and called into question as a fixed, non-religious position (Taylor and Snowdon 2014). In short, no position is safe or stable from a queer perspective.

As subject positions, identities, and bodily experiences merge within complex networks of norms, the content of a queer theoretical approach seeks to engage and disrupt these norms, or at least describe and expose them (Schippert 2011). What is interesting from a queer-theoretical perspective is to see how religious norms are socially produced and maintained, and what consequences these norms have for people about to leave their religion.

Therefore, reconciliation or disaffiliation with religion should not be considered a static two-sided coin (that is, believing or not believing) but rather as a dynamic process of doubt, ambivalence, and religious crisis. I therefore call for a more dynamic and intersectional approach that views unbelief and disaffiliation as processes combining various subject positions, competing values, 
interests, and rights. The concept of intersectionality indicates that for example, ethnicity, gender, and class are co-constitutive and shape one's relationship to power and oppression (Crenshaw 1991). Intersectionality has recently been extended to include sexuality, religion, and belief, as well as (dis)ability, age, and other social dimensions, to illustrate how these aspects correlate and are always in play (Kolysh 2017).

Religion and irreligiosity can therefore be understood as intersecting with other social categories rather than studied as though they operated on their own in isolation. That is, people rarely identify themselves just in terms of religious affiliation or atheist (irreligious) positions, but rather understand their religious/irreligious selves in relation to gender, class, ethnicity, sexuality, etc., and may well foreground different dimensions of these identifications depending on the circumstances. Although different perspectives will be highlighted, this chapter concentrates on the two intersections most often assumed to create the most tension, that is, religious belief and sexual orientation.

\section{$2 \quad$ Previous Research and Empirical Material}

This chapter draws its empirical examples and methodological discussion from a study of former Muslims in Sweden who were born and raised with Islam as their normative religious system, but at some point in life, often in their young adulthood, left Islam as well as their country of birth. A snowball sampling strategy was employed and two initial participants were recruited from within my own personal network. The two initial interviews were conducted face-to-face while the other interviews were conducted via email, mostly due to geographical distance. Pseudonyms are used in all cases except for Serin and Omar who wishes to use their real names. Ayman is a Shiite Muslim from Lebanon, Abs is also of Lebanese origin but was raised as Sunni. Serin is a 40-year old woman from Jordan. Taym is from Syria and Omar is from Egypt.

They all display ways to disconnect from religion, all of which have different characterisations (see, for example, Gooren 2010 on disaffiliation; Cottee 2015 and Zuckerman 2012 on apostasy and unbelief; Flynn 2007 on irreligiosity; and Wright et al. 2011 and Köse 1996 on deconversion and conversion). For example, some interviewees are now non-practicing Muslims who do not uphold Islamic views or rituals but still feel they belong to the community of Muslims (Umma) in the sense of "belonging without believing" (McIntosh 2015). Although they might have abandoned their religious beliefs, they have not abandoned their community. Other leave takers believe without belonging 
to the Muslim community, as in the case of many LG BTQ persons like Ayman and Abs or other migrants from Muslim countries now living residing in Sweden. Following Hervieu-Léger (2006), such an attitude can be understood as "a distant shared memory, which does not necessitate shared belief, but which even from a distance - still governs collective reflexes in terms of identity" (p. 48).There were also examples of what Wuthnow (1998) has called "patchwork religion," in which people take what they want from a religion and omit parts that do not fit their way of life, such as abstaining from alcohol or praying five times a day (see also Otterbeck 2015). A few of the interviewees stated that they were not religious at all, but were instead pursuing a quest for spirituality. There are also examples of non-attending believers and private practitioners who still felt attached to their (former) religious traditions (for example, praying when visiting the graves of family members), and examples of those who had lost faith not only in Islam but in religion entirely, like Omar and Serin. Some interviewees considered themselves Muslim just because they were born into a Muslim family, making the process of leaving the religion easier than for a formerly devout Muslim. The point is that there is a risk of relying on misleading assumptions about people who leave their religion, since current research into people who leave religion, without claiming an atheist or publicly oppositional stance against religion, is limited.

Previous studies have focused mainly on people who find ways to reconcile two often-conflicting positions (Lundqvist 2013; Yip 2005), such as "contrasting belief versus unbelief or religiosity versus atheism or agnosticism" (Streib and Klein 2013: 717), or "coping with identity threat" as Jaspal and Cinnirella (2010) puts in their study of young British Muslim gay men of Pakistani background. Other studies emphasise the eventual outcome of the conflict between sexuality and religiosity. The aim of this research is to generate a better understanding of former Muslims' own knowledge and personal understanding of what it means to be or not to be a Muslim and discuss the process by which individuals resolve this conflict by leaving Islam.

\section{3}

\section{New Findings Concerning Leaving Religion}

The decision to leave religion is not made overnight. In some cultures, leaving religion is a major move (even leading to the death penalty in some countries), a deviant act, a social risk, and, for many, a powerful personal transition. This section will examine the process of moving out of religion and give examples of the interviewees' renegotiating of their identity through a complex relationship of tension between the continuity of their former identity as Muslim and 
transformation to a new non-religious identity. In other words, we will look at the process of unfixing normative subject positions.

\subsection{The Pursuit of Autonomy}

"I was born homosexual but forced to be a Muslim," Abs told me. According to Abs, who grew up in Lebanon, he was never truly a believer:

You grow up with something. You think it is the truth because your mother and father say it is so. Like it is in every culture. My reaction was that I wanted to get to know my religion more, since it was my religion, my identity, so I wanted to go deeper.

Interview, Abs, 14/og/2016

Ayman had similar views: "I have never been a Muslim, fully. I can say that it is something I inherited. But to be Muslim or religious is not just something you are but something you have to understand" (email interview, Ayman, 10/11/2016). This same kind of reasoning was expressed in Taym's narrative. Taym grew up in Syria and was raised to be a "strong" Muslim "like everyone else." During his adolescence, Islam had a great influence on his life, but the more he got to know about his religion, the more he started to doubt his faith: "It started from small details," innocent thoughts, that were the beginning of his journey to leave Islam, he said. This left him with a desire to learn more about Islam, as he did not want to sink into what he called "fake faith":

I was stronger. I started to think more and more. I read the Koran word by word many times. It's just because I hadn't chosen to be a Muslim. For me, I wanted to be Muslim after conviction of [the truth of] Islam. That was a good motive to keep thinking. By that time I was losing my belief in Islam. I didn't pray like before. Ramadan became a normal month like other months. I found a lot of injustice in Islam. And that Mohammad was such a mean and criminal person.

Email interview, Taym, 26/11/2016

This pursuit of autonomy as a long-term gradual process of stepping away from one's previous religious environment (Streib and Klein 2013: 717) often includes "finding oneself" on the basis of one's own choices and individual identity, which could sometimes lead to "a struggle within," as Abs said. After leaving Lebanon to study in Berlin, Abs became very involved in learning more about the teachings of Islam. He went to the mosque regularly and talked with his friends about important religious questions. Subsequently, one day he 
discovered that some important values and matters in his life were not compatible with the teachings of Islam, such as being a homosexual. "I sometimes prayed to God during Ramadan to fix me, to make me a heterosexual," Abs said, adding that he knew that all people know, within themselves, what is "right" and what is "wrong." Abs knew that there was nothing wrong with being homosexual. This was the point of no return, when Abs decided he was finished with Islam (Interview, Abs, 14/og/2016). This pursuit of autonomy can also take other forms, in some cases leading to rebellion against one's upbringing and a rejection of religion altogether. Serin, a woman in her forties who was born in Jordan, changed her views of Islam at the age of six, when she moved to live in Saudi Arabia. Serin believed that religion should be a free choice, "not a mandatory law or lifestyle":

At that time, my image of God changed from that of a god of tolerance and love to a god of power and control. I started to feel that I wanted another God - their God would not represent me, would not accept my faults. I was scared of the dark, of voices, of everything. I felt controlled by Allah, whom I never saw.

Email interview, Serin, 06/07/2017

Omar, who identifies as an ex-Muslim and anti-theist explain his relation to Islam in similar words as Serin:

Religion meant a lot to me, it was the main lens throughout I saw everything, what I pereceived (sic!) as true or unture (sic!), good or bad. I was brought up in a conservative sunni family and raised as a devout Muslim and I had been so for the majority of my life up until I started studying the scripture myself. However after havig (sic!) left Islam, I became to regard it as what it is a tool of oppression, runs counter to reason, science and the values of human rights, and hence my opposition to it as an ideology.

Email interview, Omar, 29/06/2017

Although both Serin and Omar has now rejected Islam entirely, the journey of abandoning Islam was not easy, it was laden with emotional and intellectual struggle. For both it was a gradual process that took place over several years, while studying the Islamic scriptures and early history of Islam. Omar explains that there is a quote saying: "The best cure for religion is studying the scripture" (email interview, Omar, 29/06/2017).

Even if some interviewees might express considerable disbelief in God, this might not be enough to reject religion in its entirety. It could instead be 
regarded as negotiation with their religion of birth and the dominant discourse on what one should believe and do as a Muslim - "the pressure from others that you should pray, fast, and practice the religion fully," as Ayman put it (interview, Ayman, 10/11/2016). Possible discrepancies between religious faith and obligations to perform rituals and other religious duties, often combined with pressure from society and family, were the main causes of the rejection of religion. Enstedt (2018: 83) argued in his study of apostasy in Sweden that "while one's religious beliefs can be abandoned, or denounced as in an apostasy narrative, the faith can be intact and so can habits and practices, norms and values, that are deeply connected with, in this case, Islam. One can therefore leave the social and belief aspects of religion but still be religious in a range of other aspects." The next section will discuss the influence of the social environment and how migration can affect both the self-understanding and identification processes.

\subsection{Experience of Migration}

After migrating to Sweden, many of the informants' views of other, nonreligious aspects of life, such as politics and family, changed. The important change for Abs regarding sexuality was his developing individualism when it came to both sexual decision-making and forms of relationships (see also Ahmadi 2003). For Abs, being able to live as homosexual, to be himself, was possible in Sweden, and in light of that experience, he found that the social environment of his upbringing restricted him in expressing his true self before others:

I have lived here [in Sweden] for five years. I was born and grew up in Lebanon until I was nineteen, and during that time I was always super self-conscious, was in the 'closet,' did not reveal myself to anyone because I saw how other 'gay-like' boys were treated in school, in society.

Interview, Abs, 14/og/2016

Nonetheless, he claimed that many were afraid to be themselves even in Sweden. There were times when he still concealed his sexuality even in Sweden, as he was afraid to be the butt of jokes. As for Serin, the move to Sweden made her feel less isolated, as Islam was central to the culture in which she grew up. She also argued that women's space in society is very limited in Muslim societies:

Before, I thought that I was a bad person, that God would never love me or accept me because of my thoughts and opinions about him. Nowadays I feel freer, inner peace, stronger, mature, more progressive and relaxed. 
I don't need to bother myself with religious issues. Specifically, since moving to Sweden I've felt more harmony within myself and more aligned with society.

Email interview, Serin, 06/07/2017

Their encounter with, as well as their understanding of "the Swedish way of thinking" and "Swedish culture" seems to have influenced both Serin's and Abs' views of life. In Sweden, relationships are more egalitarian, and there is a relatively strong tendency towards similar views between the sexes regarding sexuality. However, this newfound freedom comes at a cost. Serin, for example, has lost most of her friends and family:

I don't socialise with my friends who became religious, and I have lost many of them. Some of them don't accept me and my thoughts. I avoid all the religious people, relatives, and my family as well. It is really a great shift in my social life - you feel like you have another identity.

Email interview, Serin, 06/07/2017

Omar's narrative shows similar traits to Serin's:

(...) it can be a struggle at times because my vocal criticism of religion and me abandoning Islam has strained my relationship with some family members and many relatives and friends, to varying degrees, including some who ever cursed me and cut off their relationship with me. It can be also challenging to be open with my views and criticism of Islam even here in Sweden, not just on account of reactions from Muslims but also from some swedes who are very politically correct and in their fear of racism have a knee jerk reaction of defending Islam itself, not just Muslims.

Email interview, Omar, 29/06/2017

It is interesting to observe the consequences of religious norms for the interviewees and the strength of the connection between religion and family. Religious leave takers - be it unconsciously, deliberately, out of necessity, or even accidentally - destabilise religious normative values and put forward different perspectives on, and interpretations of society, culture, and identity.

\subsection{The Closet Metaphor}

The metaphor of the "closet," as in "coming out of the closet," the hegemonic and quintessential gesture of LGBTQ people publically acknowledging who they really are, can also be applied to those leaving religion (see Cottee 2015). 
The metaphoric narrative of "coming out," belonging to a binary dialectic of suffering in silence versus thriving through self-expression, is useful when talking about relinquishing religious belonging and identities (see, for example, Sedgwick 1990; Seidman 2002; Plummer 1995). I will take Ayman's narrative as an example, as he refuses labels altogether, opting for an emancipation from identity constructs. He explained that it is the aspects of identity connected to sexuality and religion that are primarily the cause of all the problems, stigmas, and misconceptions about sexuality and faith:

For me it is all about not putting a label on people according to religion, sexual orientation, race, or the like. We are all equal ... It is the label, being labelled as a Muslim or Christian or Jew. I don't want that. I am a human being. I could just as well have been born into a Jewish or a Buddhist family, so it is not something you chose. ... Sexual orientation is also a label. That is why I also don't identify as homosexual. Sure, I am for the simple reason that I am attracted to the same sex, but I am reluctant to label myself as that and say that I am.

Email interview, Ayman, 10/11/2016

In relation to the closet metaphor, discussions of people's (non-)religious identity may be less interesting than discussing why some people feel it necessary to deny their sexual orientation and others to publically announce it. One must also consider that people might simply have an authentic lack of interest in religion and not be actively or consciously distancing themselves from or opposing themselves to religious values through identifying as, for instance, homosexual. Even so, when interviewed, they might retrospectively construct their religious and sexual selves as trying to find that "authentic identity" and perform it both to themselves and to those around them to show that they have shifted in orientation away from something as well as towards something new. The metaphoric narrative of "coming out of the closet" is therefore hegemonic as it is the quintessential gesture of acknowledging who one is, telling the "truth" (Enstedt and Larsson 2013). Since most people use labels as a shorthand way of conceptualising and describing their identity to themselves and others, whether aligned with religious, sexual, or other intersectional dimensions, the unwillingness to be categorised while living according to some religious expectations is in many ways queer, as it disrupts the heteronormative view of identities as unequivocal, fixed, and authentic.

It is reasonable to argue that people tend to have more fractionalised selfconceptions that reject labels with any religious connotations, but might use other types of labels to describe, for example, their political views. For 
individuals who do label themselves, a label such as "atheist" or "apostate" identifies that person's former religious identity but also stresses the oppositional current self-identification, as the "non-" prefix in non-Muslim and nonheterosexual imply. One may still acknowledge that society and culture have major impacts on a person's self-understanding and experiences of sexuality and religion. An emphasis on identification processes rather than more stable identities highlights the strategies that facilitate, or reasons that complicate, the process of leaving religion at the same time as it highlights what makes a person a believer and what does not. In such a process, people can identify several aspects of life they typically associate with Islam and being a Muslim and ascribe meaning to these aspects.

\section{4}

\section{Conclusion}

Although religion has an impact, what it means to be religious depends on many factors and may change over a lifetime without necessarily causing any major difficulties, although it also most certainly can do so. Future research into leaving religion might benefit from looking into what it actually means to claim a Muslim identity and, most importantly, into the difficulties of maintaining such an identity, for instance, in a migration situation. Research into how people construct new religious or non-religious identities by leaving or changing religion needs to be aware of the systems that push subjects towards forced identity categorisations. Research must account for both essentialist perspectives that approach sexual/religious identities as existing categories and more constructivist perspectives that actively avoid applying modern Western identity labels in other contexts. As such, a queer theoretical approach to the matter of leaving religion challenges us to think more critically about our reliance on natural bodies and authentic selves. Introducing a queer perspective to the study of leaving religion is fruitful because of the similarities between the normative and the taken for granted uncovered in heteronormativity and sexuality studies.

Studies of irreligiosity gain substantially from critical views of religious norms, doctrines, and practices as part of the great human pursuit of knowledge and power instead of accepting them as static and outside individual influence. The focus on the normative aspect of religion can help highlight and problematise the seemingly obvious in religiously lived lives, giving new dimensions to ethnological, anthropological, and sociological studies of leaving religion. By studying religiosity and the lack thereof from a starting point in what is held as normative, queer studies can serve to destabilise that 
normativity and investigate what religions hide in plain sight - deviant and queer lives - as well as questioning what is meant by terms such as "believer," "Muslim," and "religious."

\section{References}

Ahmadi, N., ed. 2003. Ungdom, kulturmöten, identitet. Stockholm: Liber.

Butler, J. 1990. Gender Trouble: Feminism and the Subversion of Identity. New York: Routledge.

Butler, J. 2003. Bodies that matter: On the discursive limits of "sex." New York: Routledge. Crenshaw, K. 1991. "Mapping the Margins: Intersectionality, Identity Politics, and Violence against Women of Color." Stanford Law Review. 43:6, 1241-1299.

Cottee, S. 2015. The Apostates: When Muslims Leave Islam, London: C. Hurst and Co. Publishers.

Enstedt, D. 2018. "Understanding Religious Apostasy, Disaffiliation and Islam in Contemporary Sweden" in K. van Nieuwkerk, ed., Moving in and Out of Islam. Austin: University of Texas Press, $67-87$.

Enstedt, D. and Larsson, G. 2013. "Telling the Truth about Islam? Apostasy Narratives and Representations of Islam on WikiIslam.net." CyberOrient. 7:1.

Hervieu-Léger, D. 2006. "The role of Religion in Establishing Social Cohesion" in K. Michalski, ed., Religion in New Europe. Central European University Press, 45-63. Flynn, T., ed. 2007. The New Encyclopedia of Unbelief. Amherst: Prometheus Books.

Foucault, M. 1978. The History of Sexuality: an Introduction. New York: Pantheon Books.

Gooren, H. 2010. Religious Conversion and Disaffiliation: Tracing Patterns of Change in Faith Practices. New York: Palgrave Macmillan US.

Jaspal, R. and Cinnirella, M. 2010. "Coping with potentially incompatible identities: Accounts of religious, ethnic, and sexual identities from British Pakistani men who identify as Muslim and gay." British Journal of Social Psychology. 49:4, 849-870.

Kolysh, S. 2017 "Straight Gods, White Devils: Exploring Paths to Non-Religion in the Lives of Blac LG BTQ People." Secularism and Nonreligion. 6:2, 1-13.

Kulick, D. 1996. "Queer Theory: Vad är det och vad är det bra för?" Lambda Nordica. 2:3/4, 5-22.

Kulick, D. 2005. Queersverige. Stockholm: Natur och Kultur.

Köse, A. 1996. Conversion to Islam: A Study of Native British Converts. London: Kegan Paul International.

Lundqvist, E. 2013. Gayted Communities - Marginalized Sexualities in Lebanon. Lund: Lund University.

McIntosh, E. 2015. "Belonging without Believing." International Journal of Public Theology. 9:2, 131-155. 
Otterbeck, J. 2015. “I wouldn't call them Muslims': Constructing a respectable Islam." Numen. 62:2-3, 243-264.

Plummer, K. 1995. Telling Sexual Stories: Power, Change, and Social Worlds. London: Psychology Press.

Seidman, S. 2002. Beyond the closet: The Transformation of Gay and Lesbian Life. London: Routledge.

Sedgwick, E.K. 1990. Epistemology of the Closet. Berkeley: University of California Press.

Streib H, and Klein C. 2013. Atheists, Agnostics, and Apostates. In I.P. Kenneth, J.E. Julie, and W.J. James, eds., APA Handbooks in Psychology: APA Handbook of Psychology, Religion and Spirituality: Vol ı. Washington D.C.: American Psychological Association, $713-728$.

Schippert C. 2011. "Implications of Queer Theory for the Study of Religion and Gender: Entering the Third Decade." Religion and Gender. 1:1, 66-84.

Taylor, Y., and Snowdon, R. 2014. Queering Religion, Religious Queers. London: Routledge. Wright, B.R.E., Giovanelli, D., Dolan, E.G., and Edwards, M.E. 2011. "Explaining Deconversion from Christianity: A Study of Online Narratives." Journal of Religion and Society. 13, 1-17.

Wuthnow R. 1998. After Heaven: Spirituality in America Since the 1950s, Berkeley: University of California Press.

Yip, A.K.T. 2005. "Queering Religious Texts: An Exploration of British Non-Heterosexual Christians' and Muslims' Strategy of Constructing Sexuality-Affirming Hermeneutics." Sociology. 39:1, 47-65.

Zuckerman, P. 2012. Faith No More: Why People Reject Religion. Oxford: Oxford University Press Scholarship Online. 